\title{
Effective Indigenization of Curriculum in Canada and New Zealand: Towards Culturally Responsive Pedagogies
}

\author{
Edward (Ted) R. Howe \\ Thompson Rivers University \\ ehowe@tru.ca \\ Shelly Johnson - Mukwa Musayett \\ Thompson Rivers University \\ sjohnson@tru.ca \\ Fiona Te Momo \\ Massey University \\ F.TeMomo@massey.ac.nz
}

\begin{abstract}
In this paper, we critically examine culturally responsive pedagogies in Canada and Aotearoa New Zealand. As each nation has a wide range of government policies and education systems, we focus our investigation on Indigenization of teacher education programs at one institution within each cultural context. We are in search of best practices in terms of Indigenizing the curriculum and effective ways to facilitate the gradual acculturation of novice teachers. Moreover, we seek to find out how these unique, exemplary programs are responding to calls to action (Truth and Reconciliation Commission in Canada and Ka Hikitia in Aotearoa New Zealand) in light of the United Nations Declaration on the Rights of Indigenous Peoples as a framework for reconciliation. The Aotearoa New Zealand Māori cultural context provides a mirror for us to reflect on Canada's curriculum reform efforts to embed Indigenous ways of knowing into teacher education. For, it is teachers who ultimately can lead the way to advancing Indigenous perspectives, reversing decades of assimilation policies, evoking social change, and providing the bridge between government rhetoric and meaningful student learning.
\end{abstract}

\section{Introduction}

The focus of this narrative paper is culturally responsive Indigenous pedagogies at two small-tomid-sized universities situated within regional communities in Canada and Aotearoa New Zealand (NZ). We investigate how each institution in a particular social, political and cultural context is engaging students with culturally relevant pedagogies to embed Indigenous ways of knowing, being, and doing into curriculum, teaching, and learning.

We begin by articulating our shared conceptual framework and our respective Canadian, Saulteaux, and Māori positionalities. We frame our study with our lived stories of education and experience, thereby providing a rationale and a global perspective. Then, we describe the national, regional and cultural contexts. Finally, we provide specific examples of how our Journal of Contemporary Issues in Education, 2021, 16(1), pp. 23-39. 
programs are Indigenizing across the curriculum and responding to calls for reconciliation. We conclude by discussing implications for Canadian teacher educators in response to Calls to Action from the Truth and Reconciliation Commission of Canada (TRC, 2015).

\section{Conceptual Framework: TRC Calls to Action}

We frame our study by acknowledging the TRC Calls to Action (TRC, 2015), Te Tiriti o Waitangi (NZ Treaty2U, 2020), and the United Nations Declaration on the Rights of Indigenous Peoples (UNDRIP, 2007).

Education for Reconciliation 62ii. We call upon the federal, provincial, and territorial governments, in consultation and collaboration with Survivors, Aboriginal peoples, and educators, to: ...[E]ducate teachers on how to integrate Indigenous knowledge and teaching methods into classrooms; iii. [U]tilize Indigenous knowledge and teaching methods in classrooms; 63ii... [Share] best practices on teaching curriculum related to residential schools and Aboriginal history; and iv. Identify teacher-training needs relating to the above. (p. 7)

We celebrate positive steps taken, and also note the persistent underachievement of Māori and First Nations students as an outcome of classroom pedagogies that fail to respond to cultural identities and lived experiences. We draw upon critical theory (Apple, 2011; Freire, 1998), post-colonial perspectives (Battiste et al., 2002; Tuhiwai Smith, 2012), culturally responsive pedagogies (Gay, 2010; Ladson-Billings, 1995), and emerging promising Indigenous relational/reciprocal practices (Battiste et al., 2002; Madden, 2015; Madjidi \& Restoule, 2008; McGregor et al., 2018).

Culturally relevant pedagogy addresses student achievement and cultural identity while offering a critical perspective to challenge inequities in schooling (Ladson-Billings, 1995). We take the position that Indigenous knowledge must provide a significant transcultural role in alleviating poverty and creating sustainable development, in conjunction with postcolonial and poststructural theories. According to Battiste et al. (2002):

Indigenous scholars discovered that Indigenous knowledge is far more than the binary opposite of western knowledge. As a concept, Indigenous knowledge benchmarks the limitations of Eurocentric theory - its methodology, evidence, and conclusions - reconceptualizes the resilience and self-reliance of Indigenous peoples, and underscores the importance of their own philosophies, heritages, and educational processes. Indigenous knowledge fills the ethical and knowledge gaps in Eurocentric education, research, and scholarship. By animating the voices and experiences of the cognitive "other" and integrating them into the educational process, it creates a new, balanced centre and a fresh vantage point from which to analyze Eurocentric education and its pedagogies. (p. 5)

In the same spirit of inquiry, this transcultural study offers one pathway to address common challenges faced by educators across Canada. The cultural context of Aotearoa NZ serves as a Journal of Contemporary Issues in Education, 2021, 16(1), pp. 23-39. 
mirror to reflect on our practices, rather than a model to adopt. Next, we introduce ourselves using a storytelling process to position ourselves within this study.

\section{Fiona Te Momo / Māori Positionality Statement}

Aotearoa NZ's education system is founded on a western epistemology. Attempting to change this system to incorporate Indigenous ways of knowing is about changing attitudes and behaviour established by colonial powers. Since the 1870's, Māori children were forced to attend state education programmes and learn western culture (Barrington, 2008; Parliamentary Counsel Office, 2020). The Crown passed legislation where it was compulsory for Māori children aged 7 years upwards to attend primary schools to learn western knowledge and forego their Indigenous knowledge. Māori people who lived in urban areas were indoctrinated into this system swiftly whereas those who lived in rural Māori communities continued to retain their language, customs, and educational practices founded on Indigenous knowledge (Barrington \& Beaglehole, 1974; Calman 2020).

My grandparents survived this indoctrination and retained their language and customs as native speakers of the Indigenous tongue. Their tribal villages were in the rural areas on the East Coast of Aotearoa NZ. However, my mother could not escape the advancement of the western education system that created native schools in rural areas, and she was strapped, belittled, and ridiculed at these schools by the European teachers for speaking the Māori language (Whangara, 2020). For her protection, my grandparents stopped speaking and teaching her the Māori language so she would learn and speak the English language. She passed the European vision on to my siblings and me that learning the English language, and forgoing the Māori language, was the only way to survive in the world. But, growing up in a community where about $50 \%$ of the population were Māori, and the English and Māori languages were spoken regularly, ensured the native language was not lost and connections to our tribal villages were sustained. At high school, I learnt the culture of people from India, the history of Greek gods and Egyptian pyramids, and the art of famous Italian painters. My Māori culture was taught as an option and confined to singing songs and learning the actions to them, but I didn't learn about our Māori history or the Treaty of Waitangi; rather, teachers told students that our Māori people were unintelligent because they sold their land for guns and blankets. At school, the futures for those Māori children of my generation were reported by our teachers to be in the fields and factories as common labourers. The universities were described as places for mainly white people who were intelligent, rich, and wealthy. Having worked in the fields then factories, I enrolled in university distance education as a mother with small children in my twenties during the late 1980s, challenging that educational system that indoctrinated me. I was introduced to the Treaty of Waitangi, the beauty of our language, and programmes dedicated to learning about our Māori culture in the academy. At the same time, our society was engaged in a revitalization of the education system that gave rise to Te Kōhanga Reo, Kura Kaupapa Māori, Whare Kura, and Wānanga, which were educational institutions to ensure the survival and revival of the Māori language and Māori customs (Te Kōhanga Reo National Trust, 2020). In addition, the Ministry of Education (MOE) developed policies where teachers would adopt Māori language in the curriculum and produced educational frameworks such as Te Whāriki, Ka Hikitia, Tau Mai Te Reo, Te Marautanga o Aotearoa, Mātaiako, and Te Rāngai Kāhui Ako ā-Iwi (NZ MOE, 2020). 
Being a lecturer in the university, I am encouraged by the programmes that facilitate the Indigenization of the curriculum. Professional degrees where the disciplines encourage this learning are in areas such as Education, Nursing, Psychology, and Social Work, which embed in the curriculum methods to educate students and staff in Māori language, customs, and culture. I deliver papers in the Bachelor of Social Work and Master of Social Work degree programmes where Māori knowledge is taught. Also, I am located in Te Putahi-a-Toi the School of Māori Knowledge where Māori knowledge is the founding principle from which we operate. Incorporating bicultural approaches to educating university students that grow our Māori language and Māori customs in class is important. This approach has to be delivered in a way that it is natural for me as a teacher and becomes a normal way of learning Indigenous knowledge for students, so it is mutually beneficial.

\section{Edward Howe / Settler Positionality Statement}

I am a white male settler, fifth generation Canadian, and father of three bi-cultural children. My family were among the early Kamloops homesteaders of the late 1800's, and I now call Kamloops home though Victoria, British Columbia (BC) is where I grew up in the 1970's. I was raised in a privileged middle-class, predominantly white neighbourhood. It was not until many years later, in the 1990's as an adult, that I personally experienced racism or othering. It was then I began to critically question my own positionality and to better understand the implications of Canadian multiculturalism policies. I have lived and worked as a racialized other for 14 years in Japan, a highly homogenous and ethnocentric nation. I consider myself an ally of Indigenous peoples.

As an elementary student, I learned about West Coast Indigenous Peoples, but they were presented as a rarefied, foreign, exotic, and distant culture, as if they were an ancient civilization. We studied First Nations traditions, but we did not critically question the assimilation policies of the government, nor did we learn about Indian Residential Schools, the Sixties Scoop, or the systematic stripping of culture. Recently, in my teaching of History of Education to teacher candidates, I have had the opportunity to deconstruct my own conceptualization of decolonization in response to Calls to Action from the TRC. It has been a humbling experience.

When I moved to Thompson Rivers University in 2014, one of the first courses I was asked to teach was History of Education. This core educational foundations course is not popular because many Bachelor of Education students often do not see the relevance of history in classroom teaching. It is challenging to teach educational foundations courses, but I was keen to make this course relevant and to introduce students to teaching for social justice, decolonization, and reconciliation. While First Nations history was embedded in this course, it was buried in a textbook that was written many years prior to the TRC. So, I attempted to find ways to update the curriculum and to Indigenize my teaching by reaching out to Indigenous faculty and the community. One of the most memorable lessons was a field trip to our local Secwepemc Museum situated next to the Kamloops Residential School, which to my surprise was still in operation until 1996. The teacher candidates watched a documentary and were given a presentation, as well as a guided tour of the school. We ended the lesson with a talking circle Journal of Contemporary Issues in Education, 2021, 16(1), pp. 23-39. 
facilitated by an Elder who was a residential school survivor. This was a very moving experience for me. Some students were brought to tears. It was particularly difficult for those of us who had grown up in a Christian home to see what had transpired at the hands of the Catholic church and the Anglican church (my own faith). But it was later I came to understand the lived experience of this Elder survivor. I interviewed her on a cold winter's day beside the Thompson River where she recounted her story. I will never forget the look in her eyes as she told me of the abuse she endured as a little girl, removed from her parents. I was shocked by the harsh words she used to describe Sir John A. MacDonald, our first Prime Minister and a man that I had been taught to admire. In June of 2015, I witnessed history in the making when Justice Murray Sinclair presented the TRC Report and addressed Prime Minister Justin Trudeau in the House of Commons. It was especially meaningful to me in light of this critical incident. This was a turning point for me on my reconciliation journey.

Across Canada, universities are leading the way in our response to calls to action from the TRC (2015), but we have much work to do. At formal gatherings, we begin by a territorial acknowledgment. But we must go beyond merely reciting a highly scripted text. As Chair of the School of Education, I have initiated a new oral tradition whereby we start our meetings with a story of experience, tied to the land. In this way, each of us reflect deeply on our own personal and professional response to the TRC. This study has prompted me to reach out to faculty to make deeper connections to the TRC and to honour the Indigenous Peoples who have inhabited these lands for thousands of years. I am currently immersed in a self-study of reflexive turns, which I believe could provide all educators across Canada and elsewhere with a path forward, as we struggle with the challenges posed by truth, reconciliation, and decolonization (Howe \& Cope Watson, 2020).

\section{Shelly Johnson / Mukwa Musayett - Saulteaux / Ojibway Positionality Statement}

Indigenous positionality privileges and informs my contribution to our study and frames my lived stories of education and experience through four examples. My parents met in the 1950's in Canada. My father is Saulteaux/Ojibway, and my mother is of European descent. During the 1950's in small-town Saskatchewan, romantic relationships between Indigenous and nonIndigenous peoples were rare and racially problematic. Due to racial tensions and for better economic opportunities, my parents moved to a small town in Dakelh territory in central BC. They both worked in the lumber industry, married, and raised my younger brother and me. My first educational experience that connects my Indigenous identity to the Canadian education system happened in my first school year. A six-year-old child made my Saulteaux Ojibway identity visible during my first week as a first-grade student in a rural, central BC public elementary school. She was one of the approximately twelve girls who attended my sixth birthday party in September of 1967, Canada's Centennial year. The next day she stood before all our first-grade classmates to tell about her experience during "show and tell." I recall being excited to hear what she had to say and was stunned when she remarked how many "Indian" people were at this birthday party. I could not understand why she had said that because there were only other first graders, my brother, parents, grandparents, aunts, uncles, and cousins at the gathering. Confused, I ran home after school to tell my mother what was said, sure that my little friend was mistaken. I recall that my mother listened to the story, and then she quietly took my 
hand and said that it was true. She said that my father was an "Indian," and so was his mother, his brothers and sisters, and their children. Gently, she told me: "That means that you are an Indian too, Shelly, and so is your brother." This was my first understanding that my racial identity, and that of my brother and father, was different from my mother's. Until that day, my paternal grandmother, aunts, uncles, and cousins were just family members. After that day, I was keenly aware that our racial differences were visible to others.

During my first five years of public school, there were only six other Indigenous students in our school population of 250. During my fifth grade, a family group of six Indigenous children began living with a white foster family in our school district. Those six children remained with their foster family for years, and we grew up together. They brought our Indigenous school population to twelve or 4.8 percent of the total. The reality is that all six of those children died before my thirtieth birthday in drowning accidents, car accidents, from drug overdoses, and a house fire. These experiences and those of my own family profoundly altered my perceptions of Indigenous reality in Canada. Generally, it shaped my understanding of the differential ways that Indigenous peoples' lives are affected by intergenerational impacts of Canada's Indian Residential Schools, the Canadian child welfare system, disconnections from traditional lands and resources, disruption in family and community bonds, public education, and poverty. Specifically, it compelled me into a social work career spanning two and a half decades in BC, along with a determination to practice with authenticity, compassion, and advocacy.

A second pivotal educational moment occurred in 1971, during my fifth grade, when my classroom participated in an international elementary teacher exchange. It sent my white teacher to Australia for a semester and brought an Australian teacher to our Canadian school. His name was Peter Bliss. He was a Koori teacher from Brisbane, and we came to understand that meant that he was an Indigenous person. Mr. Bliss held a parent-teacher interview that semester, the only public school parent-teacher meeting that my father ever attended. The next day, Mr. Bliss spoke to me privately for less than one minute. He said,

Shelly, I know that you are an Indian child because I know who your father is. I want you to know that you are a smart girl, and you can be just as successful in school as any other student. Other people might try to tell you differently, but I want you to always remember what I say. You will do well in school, and you must ignore people that say you cannot. He waited for me to nod my head, patted me on the shoulder, and then sent me back to my desk. He was right. I have never had a chance to tell him that our one-minute conversation sustained me through difficult times in elementary school, high school, and two undergraduate degrees.

The third educational experience that informs my post-secondary researching and teaching occurred when the second Indigenous teacher entered my student life. This happened nearly 30 years later, in 2000, during my Master of Social Work program at the University of Northern British Columbia. Her name is Dr. Margo Greenwood, and she is a Cree woman from Alberta. There were no other Indigenous students in that MSW program, and her mentorship and presence in my learning was instrumental in helping me to find my voice in my coursework and research. I chose a thesis option at her urging and researched the leadership influences of First Nations women chiefs in northern BC (Johnson, 2001). It proved to be a watershed moment in my own educational journey and learning.

Journal of Contemporary Issues in Education, 2021, 16(1), pp. 23-39. 
The fourth pivotal educational experience occurred in 2006 when I entered an Indigenous doctoral program at the University of British Columbia in Vancouver. I began the program in my mid 40s, after a twenty-five-year career as a BC provincial social worker, manager, and Chief Executive Officer of an urban-based Indigenous child and family delegated agency. I was one of fifteen Indigenous people among seventeen in the first Indigenous doctoral cohort. Two nonIndigenous students joined the cohort due to their long-term relationships with Indigenous agencies and colleagues. Indigenous instructors and professors led and informed all the curriculum and teaching, and they belonged to various Indigenous nations living in Canada, Australia, Aotearoa NZ, the United States, Inner Mongolia, and South America. Indigenous authors informed readings and presentations on Indigenous topics in education. My doctoral experience offered a unique learning opportunity in which every single Indigenous cohort member felt transformed. It was sobering to see and experience its impact on the two nonIndigenous students who were the first and only students to withdraw from the program. Personally, I thrived in UBC's first and only Indigenous doctoral program to date. Its very existence put into words and actions the possibilities of Indigenous ways of knowing, being, and doing in educational settings. In 2011, I was the first in the cohort to defend my dissertation. Previous personal experiences and social work knowledge led me to explore the educational experiences of traumatized Indigenous children living in the BC foster care system. Lessons learned in the doctoral program continue to inform my own Indigenous ways of knowing, being, and doing curriculum development, teaching, and researching in post-secondary institutions in $\mathrm{BC}$, as it does for the other Indigenous members of my cohort. Today, that knowledge and experience shapes my work as a Canada Research Chair in Indigenizing Higher Education and as an Associate Professor.

In the past four years, I have developed a graduate level Education course on Indigenous research methodologies, protocols and practices, and another on Indigenous oral traditions and storywork. I will describe and review the first course below. International and domestic students and a wide range of community members benefit from the existence of this course. Its intention is to expose graduate education students to Indigenous research methodologies to improve the ways in which research is undertaken in collaboration with, and for the primary benefit of Indigenous peoples and communities.

\section{Indigenous Consciousness and Culturally Responsive Teaching}

Our world is facing numerous global crises in 2020 including a pandemic, climate change, peace and human rights, geopolitical instability, and other significant challenges that threaten our collective futures. The time is ripe for Indigenous perspectives and new holistic approaches to curriculum, teaching, and learning. All these issues have recently come to a head, threatening Canadian unity. For example, in 2020, Canada is experiencing unprecedented competing agendas for and against pipeline construction, energy development, and Indigenous sovereignty. Now is the time for reflection and critical dialogue throughout post-secondary institutions, particularly those that accept funding from resource extraction companies. 
How have we as global citizens ended up in this situation where many children are living in poverty, while others are growing up largely naïve and unaware of pervasive equity issues? Access to inclusive human rights-based, responsive quality education should be our major consideration as educators. In a digital Internet era of "fake news" and the advent of social media replacing legitimate sources of information, we need transformative teachers and to be guided by the wisdom of Indigenous Elders. There is a strong need for today's teachers to embrace critical media literacy, critical pedagogies, and global citizenship education (Howe, 2014). Transformative teaching for social justice and Indigenous ways of knowing offer the next generation a sense of hope. BC's new holistic curriculum and NZ's Tātaiako: Cultural Competencies for Teachers of Māori Learners show great promise (BC MOE, 2020; NZ Teachers Council; NZ MOE, 2011). Both curriculum frameworks provide teachers with opportunities to effectively integrate Indigenous perspectives from pre-kindergarten through grade 12 and to use Indigenous pedagogies to address many global issues we face.

\section{Culturally Responsive Pedagogies From Across the Pacific}

Aotearoa NZ has a diverse population of about 5 million people, of which approximately $16 \%$ are Māori, 75\% are European, 12\% are Asian, 8\% are from other Pacific nations, and 1\% other ethnicities (Statistics NZ, 2020). Although the Māori language is currently only spoken by approximately 1/4 of Māori adults (Statistics NZ, 2020), the Early Childhood Education Kōhanga Reo (Language Nests) are at the forefront of support for protecting and revitalizing the language following near extinction in the last century. All teachers must study Māori language as part of their training and are expected to use it.

Aotearoa NZ's teacher education leads the way, providing opportunities to engage in culturally responsive pedagogies incorporating Māori ways of knowing (Alcorn, 2014; Glynn et al., 2010; Trevethan, 2017). Standards for teachers have been developed that embed traditional Māori ways with cultural competencies for teachers (NZ Teachers Council; NZ MOE, 2011). All teacher education providers are required to gain re-approval for new qualifications based on the requirement that graduating teachers demonstrate they understand and recognise the unique status of tangata whenua in Aotearoa New Zealand; understand and acknowledge the histories, heritages, languages and cultures of partners to Te Tiriti o Waitangi; and practise and develop the use of te reo and tikanga Māori.

Indigenizing the curriculum requires designing the course of study to implement compulsory papers in Indigenous knowledge. Students in my (Fiona's) classes on Māori knowledge are exposed to the Māori language and Māori culture from the beginning. We, the students and I, begin and end each class with a karakia (prayer) followed by waiata (songs) before reverting to the English language. In the first week, I start to deliver the karakia, and from that week onwards students take turns speaking the Māori language. Course literature and readings are published by Māori authors, and the selection of documentaries or videos viewed in classes, or uploaded to the online student sites, are of Māori leaders or Māori communities discussing issues like Māori economic development, Māori political development, or Māori social development. The content is laden with mātauranga Māori (Māori knowledge) drawn from the many published articles by 
Māori authors, steeped in their traditional knowledge with strong connections to their communities.

Teaching students about Māori knowledge requires going into the community amongst the tangata whenua (people of the land). Students who undertake a professional degree like social work participate in a field trip stay-over on a marae (Māori tribal house) to learn about the Māori community and work with each other outside of the academy. At least a year in advance of any marae stay-over, I ensure there is an established relationship with the kaumātua (Elders) and mana whenua (tribes who hold autonomy over the land where we will stay). Customs and protocols are discussed between kaumātua, staff who will attend, and me so we are prepared and adhere to traditional practices, which are relayed to the students. The students in the classes I teach are predominantly non-Māori, and the curriculum is designed so that at least one paper in each of the first, second, and third years of an undergraduate degree adopts a type of delivery to implement learning about the Māori language and customs. The students are not taught to speak the language fluently because that is a different degree pathway; however, they learn in stages how to broaden their knowledge in the Māori culture and work with, and alongside, Māori people.

Delivering Indigenous content in the curriculum is strengthened by my experiences and genealogy. Often, those who learn Māori knowledge from only the academy and have not experienced working with or living amongst our Māori people, or do not have strong connections to their own tribal areas, struggle to determine when knowledge or practices are helpful or harmful. Those fortunate to have tribal Elders that are fluent in our language, still alive, and exercising our customary practices, like myself, can return to them for assistance when delivering programmes in the academy. The academy also brings these Elders in as guest lecturers or consultants because of their expertise in traditional Māori language and customs. Therefore, Indigenizing the curriculum includes exercising our Māori language and customs inside and outside of the academy, being proud to be Māori, and retaining connections to our Māori communities. Also, our kaumātua and people become the critical conscience of our education systems and pass on their critiques to us as Indigenous academics to address, so that the experiences of our children and grandchildren in the education system are different from the generations before us. Although a lot of positive advances in the education curriculum have occurred between being forced in the late 1800s to only learn western knowledge to embracing Māori knowledge in the 2020s, there is more work to be done to grow Māori knowledge across all disciplines in the academy and continue to Indigenize the curriculum. Clearly, there are strong parallels to the Canadian First Nations Principles of Learning as we shall see in the next section.

\section{Thompson Rivers University Indigenization of Curriculum, Teaching and Learning}

Indigenous ways of knowing are embedded into all programs at Thompson Rivers University (TRU) as this is part of the mission statement. Our Bachelor of Education (BEd) programs have a First Nations course, and we have developed Secwepmec language courses. In addition, TRU offers a suite of Master of Education courses focused on Indigenous ways of knowing: Learning from the Land; Healing from the Land; Indigenous Literature; Indigenous Research Methodologies; and Privileging Indigenous Oral Traditions and Storywork in International Journal of Contemporary Issues in Education, 2021, 16(1), pp. 23-39. 
Indigenous Research. To address the TRC's (2015) recommendations, the History of Education course critically examines our shared history, unpacking the colonial past and postcolonial response with a moving, reflexive, guided tour of the Kamloops Residential School/Museum by a local Elder, who is a residential school survivor. In addition, at the start of our BEd program, students and instructors attend a retreat for place-based learning, including an Indigenous ethnobotany walk. Educational foundations courses and methods courses each have classroom visits by local Elders to teach talking circles, storytelling, tobacco ties, and other Indigenous pedagogies. Thus, literacy, math, science, fine arts, and other subject area specialists are actively engaging our teacher candidates in exploring curricula that embed Indigenous ways of knowing. Recent work at Thompson Rivers University shows great promise. For example, in 2019, we began an Indigenous teacher candidate cohort, and we conducted an equity circle including faculty, teacher candidates, and Indigenous members of the community. New graduate courses further enhance Indigenization. To illustrate some of these initiatives, we share the Indigenous pedagogies embedded in Shelly's Indigenous Research Methodologies course.

\section{Indigenizing the Curriculum - But How Do You Do It? One Example from Canada}

Indigenization of curriculum in higher education during an era of reconciliation begins with acknowledgements that Indigenous rights are inherent rights and responsibilities. These rights are enshrined in Treaties, the Canadian Constitution, international agreements, and many postsecondary strategic plans (TRC, 2015). Indigenization requires recognition of historic wrongs committed against Indigenous peoples in Canada and a need for redress (Canadian Association of University Teachers, 2016; TRC, 2015; National Inquiry into Murdered and Missing Indigenous Women and Girls in Canada, 2019; UNDRIP, 2007). The responsibility to develop Indigenous curriculum for delivery in mainstream post-secondary institutions requires the contributions of all, along with careful consideration of a number of questions and issues. It also requires that we work with intention and collective motives, and that we know why we are doing this work towards improving curriculum for reconciliation. The work of Indigenization requires a commitment to undertake proactive measures aimed at restoring, renewing, and regenerating Indigenous practices, languages, and ways of knowing, being, and doing in post-secondary institutions (TRC, 2015). A place to start Indigenizing the curriculum is with five basic questions:

1. What does it need to be possible?

2. Who needs to be involved?

3. What are their roles and responsibilities?

4. Where and when does it happen?

5. What are the ways in which it happens, or how do you do it?

While these can be questions to consider during the development of any curriculum, it is also important to frame them with considerations of what reconciliation means when we are working towards Indigenizing the curriculum in post-secondary. In this section, we acknowledge that there are many paths to reconciliation. We also acknowledge truth in the metaphor that Indigenization can be like trying to pour a foundation after the house or post-secondary institution is built. It must be more than "adding Indigenous content" and stirring. 
Indeed, a Canadian university-based based article by Adam Gaudry and Danielle Lorenz (2018) titled, "Indigenization as inclusion, reconciliation, and decolonization: Navigating the different visions for Indigenizing the Canadian academy," explores the ways to ethically engage Indigenous communities and knowledge systems. This article was written based on the results of an on-line survey of 25 Indigenous faculty in primarily mainstream Canadian Indigenous studies programs. It advocates for the transformation of the academy in moving beyond its narrow conceptions of what constitutes knowledge, and it advocates that Indigenization must mean more than increasing student enrollment and hiring more Indigenous faculty and staff. The authors identify three meanings of Indigenization that exist on a spectrum, two of which are clearly articulated and a third that is developmental. Specifically, these three meanings of Indigenization are Indigenous inclusion, reconciliation Indigenization, and decolonial Indigenization.

One example of all three expressions of Indigenizing the curriculum in Canada is a Master of Education course developed and taught by Shelly at TRU in 2018 and 2019. The idea for the course arose in a 2017 conversation with the Dean of Education once Shelly was appointed to the Canada Research Chair in Indigenizing Higher Education. The Dean is a woman of Samoan descent, and she asked: "Which Master's course do you want to teach?" to which Shelly replied, "The Indigenous Research Methodologies course." The Dean informed Shelly that the institution had no such course. Shelly said that she would develop it, but that it would cost money to do it properly and would require guidance from many people. The Dean's response was, "Ok, you do that, and I will find money to support it."

In post-secondary institutions, there are many curriculum possibilities to teach in Indigenous ways, and many expectations for a hard "no" response when funding is required to do it. In this instance, Shelly's request was met with zero pushback. The reality that her request received $100 \%$ support from another Indigenous woman in a leadership position is unique. In response to question one above, Indigenization of the curriculum needs committed funding and support from post-secondary leadership. It mirrors the reality identified in the Summary report of the TRC (2015) that "getting to the truth was hard, but getting to reconciliation will be harder.

Reconciliation requires that a new vision, based on a commitment to mutual respect, be developed" (p. vi). This foundation is evident in the development of this course.

The second step in Indigenizing the curriculum involves reaching out to networks, relations, and many helping hands to ask for guidance. In this example, relations began with an adherence to a 2015 protocol between Thompson Rivers University and local Indigenous peoples, namely the Tk'emlups Indian Band, upon whose unceded lands the institution is built. An Indigenous Research Advisory Council was developed that included Indigenous peoples from three different reserve-based communities, people living in urban centres, Indigenous and non-Indigenous academics employed at the university, Elders, and students. Academics, support staff, Elders, and students from diverse faculties were invited to three separate meetings on campus to talk about our individual and collective curriculum development experiences, dreams, experiences, and ideas. Representatives from the faculties of Education, Social Work, Law, Nursing, Sociology, Adventure Tourism, Arts, Indigenous Languages, and Indigenous Services were in agreement about the importance of a "made in Secwepemc territories" Indigenous research course.

Journal of Contemporary Issues in Education, 2021, 16(1), pp. 23-39. 
In adherence to the 2015 protocol between the university and Tk'emlups Indian Band, three additional meetings were held in First Nations communities with their educational leadership. We asked to meet in their spaces, at a time and place of their choosing, to ask:

1. In what ways were their communities involved in curriculum development in the past, and what were their positive or negative experiences? What might we do differently?

2. In what ways might an Indigenous research course be helpful to the work in communities?

3. Who in their communities might contribute to the development, implementation, and review of the course?

4. What are their hopes and dreams for an Indigenous Research Methodologies course?

Once the six meetings concluded, a review of the gathered information occurred, and the results were shared with both groups. This is a critical part of learning to Indigenize the curriculum, and it results in a key third step in the process. In this step, once information has been gathered, ideas have been shared and considered, and people have provided their thoughts and guidance, it is imperative for the curriculum developer to put into practice what the people have said and shared. In this example, it meant that the curriculum would be delivered in the following ways.

1. Each class would begin with a half hour Secwepemctsin language lesson. This is the language of the local First Nations groups. In the first year, a fluent Secwepemctsin language teacher employed by the university provided this education, and in the second year it was provided by contract. The language teacher was also tasked with evaluating the students' Secwepemctsin learning.

2. The course would physically begin on the land and be guided by Secwepemc Elders. In both years, the first class was held at the local Secwepemc Museum at the Tk'emlups Indian Band. Elders and curators taught a combined total of 33 students in a traditional pit house dwelling and through a tour of the lands, plants, and topography. In other classes, Elders were brought into the classroom to teach drum and drumstick making, using personal instruction, storytelling, and videography. Former Indigenous students also taught students pow wow dancing and singing, and they accompanied students to the legendary Y powwow.

3. $50 \%$ of classes would be held on campus and $50 \%$ would be held in community.

4. Faculty from the aforementioned faculties would contribute their expertise and research methodologies to guest lecture and co-teach for one hour of each class using a research methodology of their choosing. The final hour and a half would be the responsibility of the course instructor.

5. All three assignments in the course would use oral traditions, and there would be no written papers.

6. A rubric for grading was created with colleagues and Elders.

7. Flexibility in the curriculum would be encouraged so that students could participate in experiences such as the Y powwow or the Indigenous National Gathering of Graduate Students to learn from both community-based peoples, traditional teachings, and national and international scholars. 
8. Over the course, students would develop relationships with community-based teachers and colleagues, and invite them to their final presentations and potluck gathering.

9. The course financial requirements would be transparent and accountable to the Dean and Master of Education Committee as the funder, and the final costs would be communicated in writing in a timely way.

The fourth step in Indigenizing this curriculum is the continual review of articles on the topic (Mihesuah \& Wilson, 2004; Pete, 2016; Pidgeon, 2016; Pidgeon et al., 2014; Sasakamoose \& Pete, 2015; Tuck \& Yang, 2012) and through solicitation of feedback from students and community members. Feedback-gathering in this instance was facilitated via an informationgathering talking circle, the institutional internet-based course review process, by telephone, and in person. Feedback is reported out through storytelling with colleagues, in conference presentations, and in scholarly writing such as this article.

\section{Student Outcomes and Examples}

In the first year of the Indigenous Research Methodologies course, the Social Sciences and Humanities Research Council of Canada (SSHRC) funding body issued a call for small Indigenous community-based grants up to $\$ 50,000.00$. The students' final assignment asked them to work with Indigenous agencies or communities to identify and determine what research needs could be met by the grant. They were expected to work in groups and to present their findings along with their research partners on the final day of the class. One student group worked with a community-based agency to identify the need for second stage recovery housing in the community. Their work was so compelling, and supported by community funding, that I (Shelly) encouraged them to actually apply for the SSHRC grant. Many revisions later, the $\$ 50,000.00$ grant application was submitted to the SSHRC national call, approved, and implemented. It was a stunning outcome for a First Nations Master of Education student who had not completed all the course assignments required for graduation prior to becoming a successful grant applicant.

In the second year of the course, a First Nations Master's student approached me to be his research project supervisor. His idea was to complete a project exploring Indigenization curriculum initiatives in three reserve-based schools on Secwepemc territory. During his final presentation, representatives from Indigenous schools attended and made public commitments to enact his recommendations. As a direct result of his presentation, he was recruited to teach an Indigenous studies course at a regional community college. He is now in his second year of teaching.

To date, thirty-three students from India, Bangladesh, Mexico, China, Inner Mongolia, and those with various First Nations and Métis ancestry can now speak introductory Secwepemctsin. Thirty-two students have knowledge of the teachings of traditional drums and drum making and can sing a traditional song to honour women in their families and communities. All the students identify that they have a better understanding of the ways of (1) developing relationships with Indigenous peoples, (2) traditional Secwepemc values and beliefs, and (3) researching in Indigenous ways that are meaningful to Indigenous agencies, communities, and peoples. The 
number one recommendation of the students who have completed this course is that it becomes a mandatory course for all students.

\section{Final Thoughts}

Systemic changes in society and meaningful education reform take time. Research consistently supports the notion that teachers tend to teach the way they were taught (Britzman, 2003; Howe, 2006). While the core of teaching in BC remains relatively unchanged over the past three decades, a great deal has changed in recent years, especially in light of the TRC Calls to Action (2015) for post-secondary, new BC curriculum that better explores Indigenous issues, and increasing numbers of post-secondary faculty of Indigenous ancestry. Moreover, with a revolving door of politicians at the helm and frequent changes in political climates, more changes are expected. However, the increasingly practical Indigenous knowledge of teachers and their relationships with Elders and Indigenous peoples is growing. The best teachers are constantly undergoing professional development (Howe, 2005, 2006, 2008). Much of this occurs on the job, through teachers' own initiatives and a growing knowledge of Canadian history from Indigenous perspectives.

Innovative Aotearoa NZ curricular reforms embedding traditional Māori ways with cultural competencies for teachers offers us a mirror to reflect on our own practices. Transformative educators at TRU are actively engaged in seeking guidance from local Indigenous peoples, through dialogue, discussion, and protocol developments. The institution is waking up to the value in following Indigenous direction. Indigenous ways of knowing and promising Indigenous pedagogies are starting to inform a collective transformative educational journey in BC.

Effective teachers are avid learners with educational experiences that are informed by Indigenous worldviews that are land-, community-, and family-based. This knowledge does not stop at the university gates, and there is a growing movement to ensure that Indigenous peoples must bring all of themselves to the university rather than to "leave their Indigeneity or pedagogies" at the gates of post-secondary. Unfortunately, government agendas can thwart teachers' efforts to engage in curriculum, teaching, and learning. With shrinking budgets and increasing numbers of international, Indigenous, and special needs students, teachers have more challenges than ever before. Furthermore, teachers are under increasing pressure to make do with less while achieving more. Neo-liberal and neo-conservative governments in $\mathrm{BC}$ and elsewhere across Canada are pushing for higher standards, stricter assessments, and greater teacher accountability. These days, teacher morale and working conditions in schools continue to be issues of concern. If these issues are not addressed, potential teacher candidates among the "best and brightest students" are likely to choose other career paths. That is an outcome to avoid. Exemplary, culturally and violenceinformed teachers with a firm grasp on Indigenous history in Canada and Aotearoa NZ can inspire teachers of the future to better shape Canadian and Aotearoa NZ society. We remain optimistic that teachers will continue to demonstrate Indigenous and culturally informed pedagogies to promote effective education in Canada and Aotearoa NZ. The educational outcomes that we work toward are effective leadership that is respectful of Indigenization, multiculturalism, racial tolerance, and global citizenship, as well as comprehensive curriculum, teaching, and learning. 


\section{References}

Alcorn, N. (2014). Teacher education in NZ 1974-2014. Journal of Education for Teaching: International Research and Pedagogy, 40(5), 447-460. https://doi.org/10.1080/02607476.2014.956547

Apple, M. W. (2011). Global crises, social justice, and teacher education. Journal of Teacher Education, 62(2), 222-234.

Barrington, J. (2008). Separate but equal?: Māori schools and the Crown, 1867-1969. Victoria University Press.

Barrington, J. M \& Beaglehole, T. H. (1974). Māori schools in a changing society: An historical review. NZ Council for Educational Research.

Battiste, M., Bell, L. \& Findlay, L. M. (2002). Decolonizing Education in Canadian Universities: An Interdisciplinary, International, Indigenous Research Project. Canadian Journal of Native Education, 26(2), 82-95.

BC MOE. (2020). Building Student Success: BC's new curriculum. https://curriculum.gov.bc.ca/

Britzman, D. P. (2003). Practice makes practice: A critical study of learning to teach. State University of New York Press.

Calman, R. (2020). Māori education - mātauranga'. Te Ara - The Encyclopedia of New Zealand. http://www.TeAra.govt.nz/en/Māori-education-matauranga/print

Canadian Association of University Teachers. (2016). Indigenizing the academy: Policy statement. https://www.caut.ca/about-us/caut-policy/lists/caut-policystatements/Indigenizing-the-academy

Freire, P. (1998). Pedagogy of freedom: Ethics, democracy and civic courage (P. Clarke, Trans.). Rowman and Littlefield Publishers, Inc. (Original work published 1968).

Gaudry, A., \& Lorenz, D. (2018). Indigenization as inclusion, reconciliation, and decolonization: Navigating the different visions for Indigenizing the Canadian academy. AlterNative: An International Journal of Indigenous Peoples, 14(3), 218-227. https://doi.org/10.1177/1177180118785382

Gay, G. (2010). Culturally responsive teaching ( $2^{\text {nd }}$ Ed). TeachersCollege Press.

Glynn, T., Cowie, B., Otrel-Cass, K., \& Macfarlane, A. (2010). Culturally responsive pedagogy: Connecting NZ teachers of science with their Māori students. Australian Journal of Indigenous Education, 39, 118-127.

http://ezproxy.tru.ca/login?url=http://search.ebscohost.com/login.aspx?direct $=$ true $\& \mathrm{db}=\mathrm{e}$ ric \&AN=EJ909879\&site $=$ eds-live

Howe, E. R. (2005). Japan's teacher acculturation: Critical analysis through comparative ethnographic narrative. Journal of Education for Teaching: International Research and Pedagogy, 31(2), 121-131. https://doi.org/10.1080/02607470500127251

Howe, E. R. (2006). Effective teacher induction: An international review. Educational Philosophy and Theory, 38(3), 287-297. https://doi.org/10.1111/j.1469-5812.2006.00195.x

Howe, E. R. (2008). Teacher induction across the Pacific: A comparative study of Canada and Japan. Journal of Education for Teaching: International Research and Pedagogy, 34(4), 333-346. https://doi.org/10.1080/02607470802401503

Journal of Contemporary Issues in Education, 2021, 16(1), pp. 23-39. 
Howe, E. R. (2014). Global citizenship education from across the Pacific: A narrative inquiry of transcultural teacher education in Japan. Cultural and Pedagogical Inquiry, 6(1), 25-42. https://doi.org/10.18733/C3HS3S

Howe, E. R. \& Cope Watson, G. (2020). S-STEP in comparative and international education: Comparative ethnographic narrative. In C. Edge, A. Cameron-Standerford, \& B. Bergh (Eds.), Textiles and Tapestries: Self-Study for Envisioning New Ways of Knowing. EdTech Books. https://edtechbooks.org/textiles_tapestries_self_study/chapter_116

Johnson, S. (2001). Reclaiming their places: Seven women chiefs of $\bar{N}$ orthern BC. [Ünublished master's thesis]. University of Northern British Columbia.

Ladson-Billings, G. (1995). Toward a theory of culturally relevant pedagogy. American Educational Research Journal, 32(3), 465-491. https://doi.org/10.3102/00028312032003465

Madden, B. (2015). Pedagogical pathways for Indigenous education with/in teacher education. Teaching and Teacher Education, 51, 1-15. https://doi.org/10.1016/j.tate.2015.05.005

Madjidi, K. \& Restoule, J. (2008). Comparative Indigenous ways of knowing and learning. In K. Mundy, K. Bickmore, R. Hayoe, M. Madden \& K. Madjidi (Eds.), Comparative and international education: Issues for teachers (pp. 77-88). Canadian Scholars Press.

McGregor, D., Restoule, J. \& Johnston, R. (2018). Indigenous research: Theories, practices, and relationships. Canadian Scholars.

Mihesuah, D. A., \& Wilson, A. (Eds.). (2004). Indigenizing the academy: Transforming scholarship and empowering communities. University of Nebraska Press.

National Inquiry into Missing and Murdered Indigenous Women and Girls. (2019). Reclaiming power and place: The final report of the National Inquiry into Missing and Murdered Indigenous Women and Girls. https://www.mmiwg-ffada.ca/final-report/

NZ Treaty2U. (2020). The Treaty of Waitangi. Museum of New Zealand. http://www.treaty2u.govt.nz/the-treaty-up-close/treaty-of-waitangi/

NZ MOE. (2020). Māori. https://www.education.govt.nz/

NZ Teachers Council and MOE. (2011). Tätaiako: Cultural competencies for teachers of Māori learners. http://www.education.govt.nz

Parliamentary Counsel Office. (2020). Education Act 1877 (41 Victoriae 1877 No 21), http:/www.nzlii.org/nz/legis/hist_act/ea18774/1v1877n21224

Pete, S. (2016). 100 Ways: Indigenizing \& decolonizing academic programs. Aboriginal Policy Studies, 6, 81-89. https://doi.org/10.5663/aps.v6i1.27455

Pidgeon, M. (2016). More than a checklist: Meaningful Indigenous inclusion in higher education. Social Inclusion, 4, 77-91. http://dx.doi.org/10.17645/si.v4i1.436

Pidgeon, M., Archibald, J., \& Hawkey, C. (2014). Relationships matter: Supporting Aboriginal graduate students in British Columbia, Canada. Canadian Journal of Higher Education, 44, 1-21. https://doi.org/10.47678/cjhe.v44i1.2311

Sasakamoose, J., \& Pete, S. M. (2015). Towards Indigenizing university policy. Education Matters: The Journal of Teaching and Learning, 3(1). https://em.journalhosting.ucalgary.ca/index.php/em/article/view/86/77

Statistics NZ. (2020). Māori language speakers. http://www.stats.govt.nz

Te Kohanga Reo National Trust. (2020) History. https://www.kohanga.ac.nz/history/ 
Trevethan, H. (2017). Educative mentors? The role of classroom teachers in initial teacher education. A NZ study. Journal of Education for Teaching, 43(2), 219-231. https://doi.org/10.1080/02607476.2017.1286784

Truth and Reconciliation Commission of Canada. (2015). Calls to action. http://www.trc.ca/websites/trcinstitution/File/2015/Findings/Calls_to_Action_English2.P df

Tuhiwai Smith, L. (2012). Decolonizing methodologies: Research and Indigenous peoples. Zed Books.

Tuck, E., \& Yang, W. K. (2012). Decolonization is not a metaphor. Decolonization: Indigeneity, Education \& Society, 1(1), 1-40.

UNDRIP. (2007). United Nations Declaration on the Rights of Indigenous Peoples. https://www.un.org/development/desa/Indigenouspeoples/wpcontent/uploads/sites/19/2018/11/UNDRIP_E_web.pdf

Whangara. (2020). Whangara School History. http://www.whangara.school/nz/WebSpace/5/ 